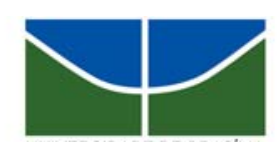

UNIVERSIDADE DE BRASÍLIA

Centro de Excelência em Turismo

\title{
ANÁLISE DA QUALIDADE DA CARNE BOVINA EM MERCADOS VAREJISTAS NO MUNICÍPIO DE BRASÍLIA - DF
}

\author{
JULIANA DE MORAIS GUEDES
}

Orientadora: Dra. Wilma Maria Coelho Araújo

\begin{abstract}
Monografia apresentada ao Centro de Excelência em Turismo - CET, da Universidade de Brasília - UnB, como requisito parcial à obtenção do grau de Especialista em Qualidade em Alimentos.
\end{abstract}

Brasília - 2006 
UNIVERSIDADE DE BRASÍLIA

Centro de Excelência em Turismo

Monografia apresentada ao Centro de Excelência em Turismo CET, da Universidade de Brasília - UnB, como requisito parcial à obtenção do grau de Especialista em Qualidade em Alimentos.

JULIANA DE MORAIS GUEDES

\section{Aprovado por:}

\section{Profa . Dra. Wilma Maria Coelho Araújo}

Orientadora

\section{Professor:}

\section{Professor:}

Brasília, _ de março de 2006. 
Dedico este trabalho aos meus pais Sueli de Moraes Guedes e José Augusto Militão Guedes pela confiança em mim depositada, pelo apoio, dedicação, incentivo, por me terem permitido chegar até aqui. 


\section{AGRADECIMENTOS}

Aos meus familiares e amigos sempre presentes e incentivando, acreditando em mim. Enfim a todos que me ajudaram e que confiaram em mim. 


\section{RESUMO}

Atualmente, a crescente exigência dos consumidores sobre a qualidade dos produtos e serviços por eles adquiridos vem promovendo um acentuado progresso quanto aos cuidados adotados pelo comércio alimentício, de uma forma geral. O consumidor vem procurando por produtos cada vez mais práticos, nutritivos e inócuos, disponíveis em estabelecimentos igualmente confiáveis e que ofereçam maior comodidade. O presente estudo, portanto, objetivou analisar a qualidade da carne bovina em supermercados, no município de Brasília, onde foram avaliadas as condições de manipulação e exposição da carne "in natura", processada a fim de constatar se a qualidade da mesma mantinha-se em condições higiênico-sanitárias adequadas. Com um termômetro e formulários de avaliação, foram realizadas quatro visitas em estabelecimentos alternados, em diferentes dias, para a obtenção dos dados requeridos nos formulários. Os resultados obtidos demonstraram que as condições de temperatura não se encontravam satisfatórias em nenhum dos estabelecimentos investigados, não correspondendo aos regulamentos exigidos por órgãos competentes, como a Vigilância Sanitária e pelas boas práticas de processamento. De acordo com os resultados, conclui-se que as inadequações dos estabelecimentos podem acarretar consideráveis prejuízos à saúde pública, sugerindo-se a necessidade da realização da correção dos fatores que se encontram irregulares.

Palavras-chave: Carne Bovina; Controle de Qualidade; Consumo; Comercialização; Brasília - D.F. 


\begin{abstract}
Currently, the increasing requirement of the consumers on the product quality and services for acquired them come promoting one accented progress how much to the cares adopted for the nourishing commerce, of a general form. The consumer comes looking for more practical, nutritional and inócuos, available, products each time in equally trustworthy establishments and that they offer to greater comfort. The present study, therefore, he objectified to analyze the quality of the bovine meat in supermarkets, in the city of Brasília, where the conditions of manipulation and exposition of the meat had been evaluated "in natura", processed in order to evidence if the quality of the same one it remained itself in adequate hygienical-sanitary conditions. With a thermometer end forms of evolution, four visits in alternated establishments had been carried though, in different days, for the attainment of the data required informs. The gotten results demonstrate that the temperature alternated the visits in accordance with, however did not demonstrate much interference in the control of the displayed product quality. One concludes that the products are being manipulated form the point of the ideal temperature not to keep the product with satisfactory quality, thus suggesting the training of the manipulators and adequacy of the personal hygienic cleaning, of equipment and utensils, since conformity cannot cause considerable damages to the public health.
\end{abstract}

Key-words: Bovine Meat; Quality Control; Consumption; Commercialization; Brasília - D.F. 


\section{LISTA DE TABELAS}

Tabela 1: Características e sintomas de contaminações 07

Tabela 2: Principais microrganismos encontrados em alimentos (bactérias) 20

Tabela 3: Principais microrganismos encontrados em alimentos (fungos) 21

Tabela 4: Conformidade e não conformidade aos parâmetros sensórias e 35 temperatura de exposição - Visita 1

Tabela 5: Conformidade e não conformidade aos parâmetros sensórias e 35 temperatura de exposição - Visita 2

Tabela 6: Conformidade e não conformidade aos parâmetros sensórias e 35 temperatura de exposição - Visita 3

Tabela 7: Conformidade e não conformidade aos parâmetros sensórias e 36 temperatura de exposição - Visita 4

Tabela 8: Resultado das Não Conformidades 


\section{SUMÁRIO}

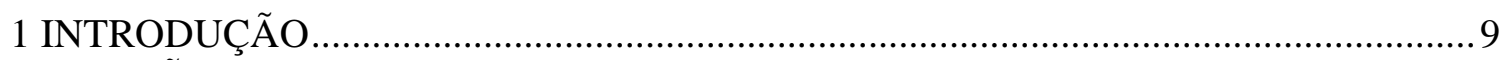

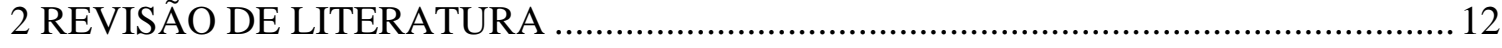

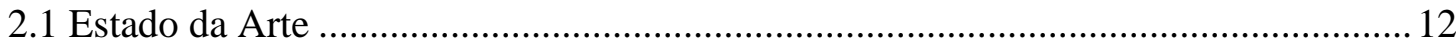

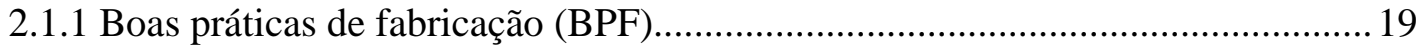

2.1.2 Boas práticas de manipulação (BPM) .............................................................. 21

2.1.3 Análise de perigos e pontos críticos de controle (APPCC) .................................2 23

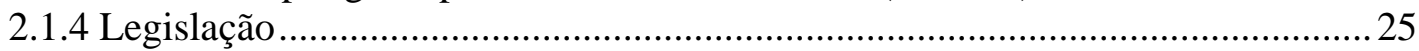

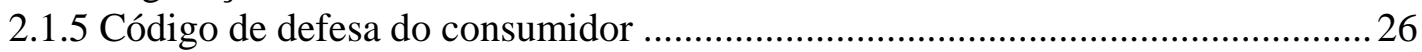

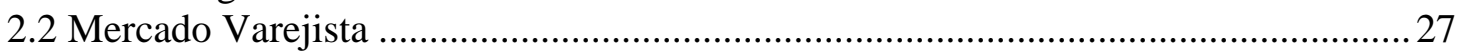

2.3 Características e Possíveis Alterações da Carne Bovina "in natura” ........................... 28

2.4 Método de Conservação Pelo Frio................................................................................. 31

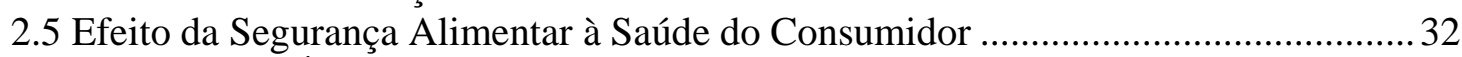

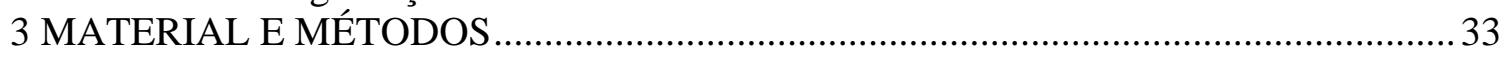

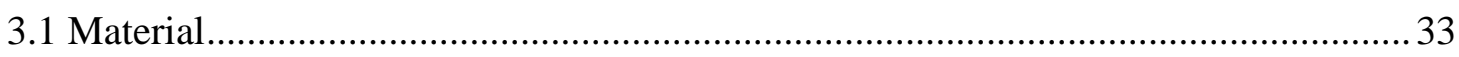

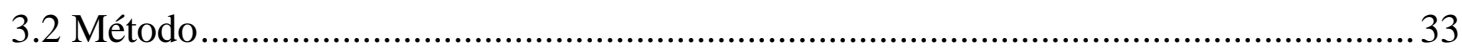

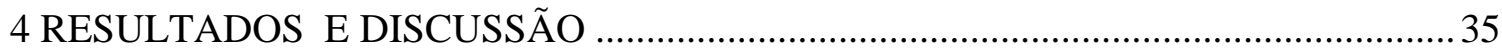

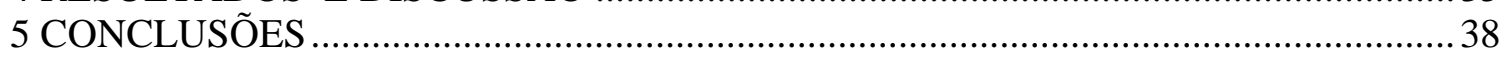

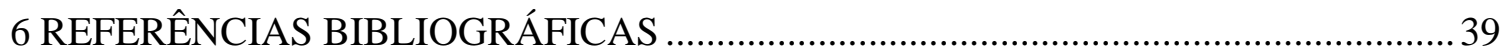

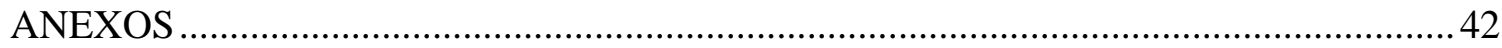




\section{INTRODUÇÃO}

Atualmente, devido à dinâmica da vida moderna e ao individualismo, os consumidores têm procurado produtos com grande praticidade e facilidade de consumo. O comércio varejista, para atender a esta demanda, passou a oferecer produtos de elevada praticidade como os fatiados, os pré-cortados e os semiprontos. Estes produtos, no entanto, exigem uma maior manipulação, o que leva a uma exigência ainda criteriosa sobre seu processamento (LIMA, 2001).

Os alimentos destinados ao consumo humano são produzidos e manipulados, muitas vezes, em locais inadequadamente higienizados, sujeitos, portanto, sujeitos a uma importante variedade e quantidade de microrganismos. Sendo assim, pode-se sugerir que o homem consome, diariamente, muitos microrganismos e até mesmo parasitos juntos ao alimento, muito dos quais patogênicos (LIMA, 2001). Neste caso, os alimentos acabam por servir como veículos de agentes patogênicos ao homem, através de contaminação e multiplicação de microbiota, principalmente os produtos alimentícios de origem animal.

Neste caso, os produtos alimentícios podem se tornar veículo de agentes patogênicos ao homem, através de contaminação e multiplicação de microbiota, principalmente os produtos alimentícios de origem animal. Produtos de origem animal, especialmente a carne bovina, são facilmente contaminados antes, durante e após o abate; bem como nas feiras livres, açougues e supermercados (BORGES, 2002).

A carne bovina é excelente meio de cultura para o desenvolvimento microbiano. Quando manipulado em condições inadequadas de higiene, causam a toxinfecção alimentar, os sintomas mais comuns são mal-estar, vômito, diarréia, febre, tontura, podendo inclusive levar à morte (LEITÃO, 1994).

O Brasil ainda não dispõe de um sistema registrados de doenças veiculadas por alimentos; portanto os dados apresentados para toxinfecções 
alimentares ainda não representam a realidade. Além disso, a maioria da população que sofre as conseqüências das toxinfecções alimentares, dificilmente procuram cuidados médicos por acreditar, equivocadamente, que esses problemas não são tão sérios, segundo o autor da matéria (o Jornal da USP (2003) - referências), a ocorrência destes problemas é, muitas vezes, interpretada como simples viroses, e assim, não são notificadas como doença transmitida por alimento, o que impede as autoridades de obterem dados completos sobre a questão devido a subnotificação.

Esta matéria relata ainda que, no ano de 2001, nos Estados Unidos, país desenvolvido, que tem uma condição sanitária e alimentar supostamente melhor que a do Brasil, país em desenvolvimento, foram notificados 76 milhões de casos de intoxicações e infecções de origem alimentar, com seis mil mortes, para uma população de pouco mais de 281,4 milhões de pessoas. Proporcionalmente, no Brasil, a estimativa é de um grande número, o que é acentuado pela desnutrição crônica e miséria em boa parte da população.

Para reverter este quadro e impedir a freqüência das toxinfecções alimentares, foram elaborados programas e planos de prevenção das doenças transmitidas por alimentos (DTA), que buscam a segurança e qualidade, como a rastreabilidade da carne bovina, as boas práticas de fabricação (BPF), boas práticas de operação (BPO), boas práticas de manipulação (BPM) que são prérequisitos para a implantação do sistema APPCC - Análise de Perigos e Pontos Críticos de Controle ou HACCP - Hazard Analysis and Critical Control Points. O conceito básico destacado pelo APPCC é a prevenção e não a inspeção do produto final, assim proporcionando uma maior segurança alimentar (STEVENSON,1995).

A Lei 8.078 (1990), que trata do Código de Defesa do Consumidor, ampara que, ao consumir um produto, seja este - "in natura" - ou processado, o desejo e o direito do consumidor é o de que o produto seja nutritivo e inócuo, não prejudicando sua saúde e nem de sua família. Ou seja, o consumidor tem o direito à proteção da vida, saúde e segurança. 
Neste cenário, o presente estudo tem como objetivo evidenciar as condições da carne bovina a ser comercializada em supermercados do município do Distrito Federal, desde a recepção até a exposição à venda final.

Especialmente a pesquisa tem como objetivo avaliar as condições de armazenamento e as características sensoriais da carne comercializada nos supermercados demonstrando a importância da presença do responsável técnico no controle higiênico-sanitário e tecnológico dos produtos de origem animal, além de conscientizar a população da importância da atuação deste profissional para saúde pública. 


\section{REVISÃO DE LITERATURA}

\subsection{ESTADO DA ARTE}

A preocupação com a qualidade dos alimentos existe desde épocas remotas, onde já se utilizavam a conservação pelo frio, fato este confirmado pela descoberta de animais expostos à congelação remontado de épocas pré-históricas na Sibéria, até então perfeitamente conservados (GAVA,1984).

Nos anos 1960, nos Estados Unidos, deu-se início ao estudo da segurança da saúde dos astronautas, para diminuir, ao máximo, a possibilidade de doenças, inclusive as transmitidas por alimentos. Em 1973, foi publicado o primeiro documento detalhando o sistema APPCC, publicada pela Pillsbury Company (SENAI, 2001).

No Brasil, a Lei 5517, de 1968, relativa às atividades de inspeção e promoção do controle higiênico-sanitário e tecnológico $(\mathrm{HT})$, é de competência privativa do médico veterinário (SANTOS, 2002).

Ainda nos séculos XVII e XIX, as atividade ligadas à vigilância sanitária no Brasil, foram estruturadas, com o intuito de evitar a propagação de doenças nos agrupamentos urbanos que estavam surgindo. A execução destas atividades, exclusivas do Estado, por meio da polícia sanitária, tinha como atividades profissionais coibir o charlatanismo, fiscalizar embarcações, cemitérios e áreas de comércio de alimentos (UNIMEVE, 2003).

Na década de 1990, no Brasil, a SEPES/MARA estabeleceu normas e procedimentos da implantação do sistema APPCC nas indústrias de pescado. E em 1993, a portaria 1428 do Ministério da Saúde estabeleceu a obrigatoriedade de procedimentos da implantação do sistema nas indústrias de alimentos a partir do ano de 1994. Em 1998, a portaria no 46 de 1998 do Ministério da Agricultura estabeleceu o manual de procedimentos para a implantação do sistema APPCC nas indústrias de Produtos de Origem Animal (SENAI, 2001). 
Os alimentos de origem animal estão sujeitos à contaminação microbiana através das inúmeras etapas do processamento industrial. O próprio animal é uma das principais fontes de contaminação, ou por microrganismos patogênicos ou por deteriorantes. Contaminações adicionais podem ser provenientes de água utilizada no processamento, equipamentos e acessórios empregados na preparação do produto e do manuseio normalmente intenso nas várias etapas da industrialização (PARDINI, 1995).

A falta de estrutura para inspecionar a qualidade da comida que chega à mesa dos brasileiros possibilita o consumo de aproximadamente $42 \%$ de carne bovina produzida para consumo imediato, sem fiscalização (MANCIO, 2001).

As doenças de origem alimentar, em especial as toxinfecções alimentares, podem ser fatais quando os agentes etiológicos são de alta gravidade, como no caso do Clostridium botulinum, Escherichia coli $\mathrm{O} 157 \mathrm{H} 7$-, Vibrio cholerae e Salmonella tiphimurium, entre outros. Há gravidade quando, também, os indivíduos atingidos possuem uma queda na defesa, ou seja, uma imunidade deprimida por doenças ou desequilíbrio nutricional. O número de surtos de toxinfecções alimentares, assim como o número de casos clínicos estimados nos Estados Unidos, é de 81 milhões de casos por ano e mais ou menos 810 milhões no Brasil neste último ano de 2000 (SILVA JR, 2001).

Quando os serviços visam à manutenção do padrão de qualidade das matérias-primas de forma a garantir a saúde do consumidor, este acaba por assimilar uma maior confiança em adquirir um alimento mais seguro, que é aquele que apresenta um risco mínimo de doença a quem o está ingerindo (SILVA JR, 2001).

Ao se referir às principais enfermidades humanas, são discutidos aspectos sócio-econômicos, epidemiológicos e de saúde pública; de maneira, as transmissões destas enfermidades são por meio da ingestão de carne bovina. No Brasil, estas enfermidades assumem um significado importante pelo fato de que 
algumas zoonoses, como a cisticercose e a tuberculose, apresentam ascensões de suas prevalência, enquanto outras, como a hidatidose, continuam a desafiar os programas epidemiológicos de controle em algumas regiões, como no Rio Grande do Sul, que já é considerado o maior reservatório dessa enfermidade na América Latina (PANETTA ,1994).

A contaminação da carne bovina pode ocorrer por via endógena (quando o animal está vivo) ou exógena, desde o abate do animal até o consumo de seus produtos. Entretanto, sua principal via de contaminação ocorre no meio externo, por exposição direta e freqüente às diferentes e inúmeras fontes orgânicas de contaminação. A prática dos princípios básicos de higiene é fator essencial na obtenção de carnes e produtos cárneos com menor índice de contaminação, melhor qualidade sensorial e nutricional (EVANGELISTA, 2000).

A manipulação alimentar pode representar uma relevante rota de propagação de endoparasitas, uma vez que a maioria destes transmite-se por mecanismo passivo-oral por meio da ingestão de cistos, ovos ou, mais raramente, de larvas infectantes livres, veiculados principalmente por água, alimentos e/ou mãos contaminadas com resíduos fecais humanos (LOURENÇO, 2002)

As características intrínsecas da carne, particularmente sua composição química, com elevada disponibilidade de água, pH próximo à neutralidade, são fatores que favorecem o desenvolvimento de uma ampla microbiota bacteriana (LEITÃO, 1994).

Com exceção da superfície externa, o trato gastrintestinal e as vias respiratórias, os tecidos de animais saudáveis contêm poucos microrganismos, devido principalmente aos mecanismos de defesa do próprio animal, controlando a proliferação microbiana. Tal fato é comprovado pela possibilidade de se obter amostras estéreis de tecido muscular, desde que se empreguem técnicas apropriadas de assepsia, no entanto, após o abate e em decorrência das várias 
operações envolvidas na obtenção final das carcaças refrigeradas, a carne passa a apresentar uma microbiota muito variável (LEITÃO, 1994).

A procedência da contaminação, em sua maior parte, é do tubo digestório, pele e pêlos, do piso, do instrumental e vestuário dos operários, da falta de hábitos higiênicos, do ar, da água e de sangria dos animais. Os cuidados higiênicos devem acompanhar toda trajetória da carne, nas câmaras frias, na desossa, no processamento, na armazenagem, no transporte, na distribuição ou no âmbito doméstico (PARDINI et al. 1995).

Entre os gêneros patológicos mais encontrados na carne, destacam-se: Salmonella sp., Staphilococcus aureus, Yersinia enterecolitica, Clostridium perfringens, Campylobacter fetus, Echerichia coli enteropatogênica e ocasionalmente Clostridium botulinum (LEITÃO, 1994).

Contaminações pela presença de Salmonella sp., Echerichia coli, Clostridium perfringens ou Yersinia enterocolica nos alimentos estão relacionadas com a via entérica, uma vez que estas bactérias são de ocorrência comum no trato intestinal de mamíferos. Com isso, fica evidente que as condições higiênicas no abate e processamento falharam, ou houve contaminação cruzada por meio de manipulação, equipamentos, vetores e acessórios, o que não deixa de ser uma falha das condições higiênicas. A presença dessas bactérias é sempre um risco à saúde pública (LEITÃO, 1994).

Ao ingerir um alimento contaminado, por exemplo, por Salmonella sp., os principais sintomas são náuseas, vômito, dor abdominal e diarréia; o período de incubação é de entre 12 a 36 horas (FRAZIER \& WESTHOFF, 1993). Em pessoas com patologias imunossupressoras pré-existentes, distúrbio nutricional, crianças, recém-nascidos e idosos, a contaminação por Salmonella sp. pode ser bastante grave (FRANCO \& LANDGRAF, 1996). Pacientes hospitalizados, imunodebilitados em pós-operatório e/ou recém-transplantados apresentam maior susceptibilidade 
para desenvolver infecção transmitida por alimentos contaminados (LOURENÇO, 2002).

Os diferentes tipos de microrganismos patogênicos quando ingeridos causam diferentes tipos de sintomas em tempo variado, como pode ser observado na Tabela a seguir:

Tabela 1: Características e sintomas de contaminação microbiana em alimentos

\begin{tabular}{|c|c|c|c|}
\hline Grupo & Incubação & Duração & Sintomas \\
\hline $\begin{array}{c}\text { 1) } \\
\text { Stafilococcus (M. } \\
\text { Pyogenes v. aureus) }\end{array}$ & $\begin{array}{c}1-6 h \\
(21 / 2-3 h)\end{array}$ & $\begin{array}{c}1-3 \text { dias } \\
\text { acasionalmente } \\
\text { mais }\end{array}$ & $\begin{array}{l}\text { Mal-estar, vômito, } \\
\text { diarréia, } \\
\text { intestinais, salicaçãa, } \\
\text { dores de cabeça, } \\
\text { cãibras musculares, } \\
\text { sudoreses }\end{array}$ \\
\hline $\begin{array}{l}\text { 2) Grupo intermediário } \\
\text { a) Strep. Fecalis }\end{array}$ & $2-18 h$ & $6-24 h$ & $\begin{array}{l}\text { Mal-estar, às vezes } \\
\text { vômitos, diarréias }\end{array}$ \\
\hline b) $\mathrm{Cl}$ perfringens & $2-22 h$ & até $12 \mathrm{~h}$ & $\begin{array}{l}\text { Às vezes mal-estar e } \\
\text { vômitos, } \\
\text { intestinais, febre e } \\
\text { dores de cabeça } \\
\text { raros }\end{array}$ \\
\hline c) B. cereus & $2-18 h$ & até $12 \mathrm{~h}$ & $\begin{array}{l}\text { Mal-estar, às vezes } \\
\text { vômitos, diarréias }\end{array}$ \\
\hline $\begin{array}{l}\text { 3) Grupo Salmonella } \\
\text { Salmonella sp. }\end{array}$ & $12-48 h$ & $1-7$ dias & $\begin{array}{l}\text { Diarréia, } r \text { cólicas } \\
\text { intestinais e com } \\
\text { certa freqüência } \\
\text { febre, náuseas e } \\
\text { vômitos }\end{array}$ \\
\hline $\begin{array}{l}\text { 3) Grupo disentérico } \\
\text { Shigella sp }\end{array}$ & 1 a 3 dias & $2-6$ dias & $\begin{array}{l}\text { Diarréia com } \\
\text { freqüentes } \\
\text { evacuações } \\
\text { mucosanguinolentas, } \\
\text { às vezes febres e } \\
\text { tenesmos }\end{array}$ \\
\hline 5) Grupo químico & Minutos & Horas & $\begin{array}{l}\text { Ansiedade, } \\
\text { excitação, vômitos, } \\
\text { dificuldade } \\
\text { respiratória }\end{array}$ \\
\hline
\end{tabular}


Fonte: SILVA JR. , 1995.

Os gastos são altos no tratamento de pessoas acometidas por toxinfecção alimentar, além de perdas econômicas pelo afastamento, dos indivíduos doentes, de suas atividades diárias. A implantação de sistemas de controle de qualidade de alimentos deve ser implantada e implementada, para se evitar os surtos de toxinfecção alimentar, pra prevenir os custos de natureza econômica e de saúde cidadãos (SILVA JR, 2001).

A segurança alimentar pode ser definida como o direito inalienável de todos os cidadãos ao acesso permanente a os alimentos necessários à saúde, em quantidade e qualidade, que a torne digna e saudável (GÓES,2001).

Os perigos podem ser introduzidos ou ampliados durante a produção nas fazendas, no momento da industrialização, no transporte, na distribuição ou mesmo no momento do preparo do alimento, o que, aliás, é comum (SILVA JR, 2001).

Relatos da Organização Mundial da Saúde e informações recentes sobre doenças de origem alimentar no Brasil, mais que $60 \%$ são toxinfecções alimentares, ou seja, os agentes etiológicos encontram-se entre as bactérias, vírus, fungos e parasitos. Isto se deve às práticas inadequadas de manipulação, matéria-prima contaminada, à falta de higiene durante a preparação, além de equipamentos e estrutura operacional deficiente e principalmente inadequação no processamento envolvendo o controle de tempo e temperatura. (FILHO, 2002).

Os fatos têm demonstrado, que somente o emprego do controle de qualidade estático e as inspeções nas fábricas não têem se apresentado efetivos no controle das doenças alimentares. Conseqüentemente, muitos produtores de alimentos optaram pela implantação de sistemas lógicos, práticos, sistemáticos, dinâmicos e compreensivos para controlar a segurança do produto (DESTRO, 1998).

Agentes microbianos, particularmente bactérias, representam um grande 
risco à saúde pública. A inspeção não deve focalizar o abate ou o processamento de alimentos; mas também, os riscos associados desde a produção no campo até o consumo. Propõe-se que os produtores utilizem medidas de segurança alimentar, para garantir produtos que satisfaçam às exigências feitas pelos consumidores (SNIJDERS, 2002).

A rastreabilidade exerce importante papel na defesa e na conquista de mercados interno e externo, principalmente pela necessidade do consumidor em ingerir um alimento seguro e saudável (MANSIO, 2001).

O produtor de gado de corte, integrado nesse novo contexto, terá condições de garantir produtos de confiabilidade. É uma demanda objetiva de qualidade e garantia no produto cárneo, com o objetivo de adquirir a lealdade dos consumidores (MANSIO, 2001).

Enquanto a inspeção ante-mortem categoriza um animal saudável, a inspeção pos-mortem identifica $20 \%$ de lesões macroscópicas, presentes em 1\% ou menos dos animais abatidos (BERENDS e HARBERS, apud, SNIJDERS, 2002). A eficiência custo-benefício e a validez científica da inspeção pos-mortem, como é feita atualmente, pode diferir de país para país (SNIJDERS, 2002).

A carne assim obtida será controlada desde a origem, o processamento e a distribuição, com identificação individual, rastreabilidade e segurança de qualidade, que garantirá a qualidade e conquistará a confiança do consumidor (MANSIO, 2001).

Estas informações são indispensáveis não apenas para inspeção, como também para administração do matadouro, que ao utilizaram como ferramenta para guiar o sistema APPCC. Com a integração dos dois sistemas, é possível que a inspeção pos-mortem seja apenas visual, com as vantagens de reduzir a contaminação secundária e a redução dos danos desnecessários à carcaça, causadas pela palpação e cortes utilizados para a inspeção atual (SNIJDERS, 2002).

Em um sistema de controle de qualidade integrado, as informações das 
fazendas são elementos essenciais para assegurar carne de boa qualidade. Rastreabilidade para todos os animais é uma condição prévia. As informações devem contemplar: a natureza e a origem da alimentação animal, o estado de saúde dos animais na fazenda, o uso de produtos médicos veterinários, os resultados de quaisquer análises feitas na fazenda, os resultados de dados de matadouro e os achados posteriores à morte (SNIJDERS, 2002).

Não poderão ser aceitos, por este controle, os animais que não tiverem as informações acima mencionadas. Caso ocorra este será abatido separadamente após a matança de rotina e serão realizados exames laboratoriais adicionais. $O$ fazendeiro terá que pagar pelos custos adicionais do exame e da inspeção (SNIJDERS, 2002).

A identificação animal é apenas a base do trabalho da rastreabilidade e atrelada a ela, estão todos os controles de movimentação, produção e sanidade dos animais. Tal exigência tem como base o regulamento $\mathrm{n}^{\circ} 820$ do Conselho Europeu de Importação de Carne (MANSIO, 2001).

Os Estados Unidos, para recuperar a confiança do consumidor, esta implantando o sistema similar ao APPCC; para eles, a segurança é o ingrediente mais importante nos alimentos (SNIJDERS, 2002).

\subsubsection{Boas Práticas de Fabricação (BPF)}

Numa época em que os parâmetros relativos à, qualidade do alimento e à segurança à saúde do consumidor são decisórios na escolha de um produto, as empresas têm buscado reavaliar seus processos, introduzindo as Boas Práticas de Fabricação (BPF) e/ou Boas Práticas de Manipulação (BPM) de Alimentos (HARES, 2000).

As Boas Práticas, enquanto pré-requisito fundamental do sistema APPCC (Análise de Perigos e Pontos Críticos de Controle), estabelece orientações gerais e específicas para aplicação nas operações de manipulação de alimentos e define os critérios que asseguram o padrão de identidade e qualidade dos produtos 
elaborados segundo tais preceitos. Enquanto o APPCC avalia e monitora todas as etapas da cadeia alimentar, aferindo e controlando fatores como: temperatura, tempo e desinfecção química, dentre outros parâmetros, a implantação das Boas Práticas avalia o ambiente de trabalho e as pessoas envolvidas nos processos produtivos, analisando basicamente os procedimentos de higiene do estabelecimento e todos os cuidados de natureza sanitária que possam interferir na integridade dos alimentos (HARES, 2000).

São as BPF/M (Boas Práticas de Fabricação ou Manipulação) de alimentos que, uma vez implantadas e implementadas, asseguram os parâmetros primários de qualidade, assim como, os procedimentos de elaboração dos alimentos e de higiene que, quando necessários, devem ser descritos. As normas descritas em ambos, manual e procedimento, devem ser conhecidas e praticadas por todos os colaboradores da empresa, em maior ou menor profundidade, dependendo da área de atuação de cada um (HARES, 200).

O primeiro passo para implantação das Boas Práticas se refere à realização do levantamento diagnóstico para avaliar o funcionamento das unidades de produção a partir da estrutura física do estabelecimento, da higiene pessoal, operacional, ambiental e as técnicas de manipulação indiretas e diretas que incidem sobre os alimentos (HARES, 2000).

As normas abrangem aspectos de nível sanitário, desde normas específicas de construção, com a finalidade de prevenir a entrada de pragas (roedores, insetos, pássaros e outras espécies de animais), e facilitar a manutenção de higiene das instalações industriais, estocagem e transporte até os cuidados no cadastramento de fornecedores das matérias primas, no seu recebimento, estocagem e manuseio, na elaboração, transporte e distribuição dos alimentos.

São abordadas também as práticas de higiene pessoal dos funcionários que se constituem no monitoramento do banho pré e pós-trabalho, na higienização das mãos sempre que necessária, na ausência de adornos, barbas e bigodes, da proteção total dos cabelos, da manutenção de unhas curtas e sem esmaltes, 
dentre outras. A conscientização e o treinamento dos colaboradores quanto às BPF/M é de fundamental importância (HARES, 2000).

Uma área de grande importância a se considerar é o ambiente de trabalho. O procedimento para a implantação da BPF/M deve ser iniciado com um projeto que torne o ambiente saudável, previna as toxinfecções alimentares e englobe as instalações, áreas de trabalho, fluxo operacional e equipamentos. A limpeza e desinfecção são operações fundamentais quando se manipula alimentos, como a maioria dos microrganismos se desenvolvem sob condições favoráveis, a desinfecção das instalações, áreas e equipamentos, reduzirá as possíveis possibilidade de contaminação (GÓES, 2001).

Estas regras, se seguidas, irão proporcionar às empresas, minimização de perdas de alimentos impróprios para o consumo devido a infestações de pragas e/ou contaminações microbiológicas por processos de higienização inadequados. O não adoção destas normas poderá implicar em aumento de reclamações quanto à qualidade do produto ou até mesmo de casos de consumidores que tiveram sua saúde prejudicada devido ao consumo de alimentos impróprios, colocando em dúvida a imagem da empresa (HARES, 2000).

A portaria no 326 do Ministério da Saúde (BRASIL, 1997) tem como objetivo, estabelecer os requisitos gerais lessenciais e de boas práticas de fabricação a que deve ajustar-se todo o estabelecimento com a finalidade de obter alimentos aptos para o consumo humano (BRASIL, 1997).

\subsubsection{Boas Práticas de Manipulação (BPM)}

Boas Práticas são normas de procedimentos para atingir um determinado padrão de identidade e qualidade de um produto e/ou de um serviço na área de alimentos, cuja eficácia e efetividade deve ser avaliada através da inspeção e/ou da investigação (BRASIL, 1993). 
As boas práticas de manipulação (GMP), são adequações das técnicas operacionais em relação aos critérios de segurança no controle higiênico-sanitário dos alimentos, são medidas mínimas necessárias aos alimentos em suas diversas etapas de produção até o consumo final. São procedimentos que descrevem tarefas de saneamento e asseguram a conservação da higiene, devendo ser aplicados antes, durante e depois das operações de elaboração de alimentos (CARVALHO, 2003).

Para serem implantadas primeiro é necessário realizar um diagnóstico da unidade de produção, preparar um Plano de Ação, em seguida implementar as BPM, depois deve-se Definir as Rotinas de Trabalho; Treinar os funcionários; Avaliar as rotinas e Elaborar Manual BPF (CARVALHO, 2003).

A educação e o treinamento dos funcionários que manipulam alimentos é o aspecto mais importante para o sucesso a implantação dessa ferramenta de segurança alimentar. A mudança estrutural de um estabelecimento será inválida se junto não houver conscientização por parte dos manipuladores, que ao serem contratados são desprovidos de treinamento na área de alimentos ou trazem experiências adquiridas em outras unidades (GÓES, 2001).

A importância do treinamento é oferecer aos manipuladores conhecimentos teóricos e práticos necessários para capacitá-los e levá-los ao desenvolvimento de habilidades e atividades do trabalho específico na área de alimentos. O treinamento deve ocorrer por meio de programas educativos por um processo contínuo e planejado, visando promover a sustentação de pessoal qualificado, satisfeito e estável (GÓES, 2001).

A falta de esclarecimento entre os manipuladores contribui de forma significativa para a contaminação dos alimentos, fazendo necessário adotar medidas sanitárias rigorosas na manutenção de um padrão adequado de higiene (GÓES, 2001).

Está amplamente comprovado que a maioria dos casos de toxinfecção alimentar ocorre devido à contaminação dos alimentos por manipuladores, 
confirmando a necessidade de treinamento periódico dos funcionários q eu atuam em toda cadeia produtiva (GÓES, 2001).

Através de eficazes e permanentes programas de treinamentos, informação e conscientização dos manipuladores é que se conseguirá produzir e oferecer ao consumidor alimentos seguros, inócuos e com propriedades nutricionais que satisfaçam a um consumidor cada vez mais exigente e informado (GÓES, 2001).

\subsubsection{Análise de Perigos e Pontos Críticos de Controle (APPCC)}

O sistema de Análise de Perigos e Pontos Críticos de Controle (APPCC) originou-se na indústria química na Grã Bretanha. Com as primeiras viagens espaciais no início dos anos 60, a NASA, nos Estados Unidos, estabeleceu como prioridade o estudo da segurança da saúde dos astronautas, no sentido de eliminar a possibilidade de doenças durante a permanência no espaço. Dentre as possíveis doenças que poderiam afetar os astronautas, as consideradas mais importantes foram as associadas às suas fontes alimentares (SENAI, 2001).

A companhia Pillsburry foi a escolhida para desenvolver sistemas de controle efetivo para a cadeia alimentar, após intensa avaliação, ela concluiu que seria necessário estabelecer controle em todas as etapas de preparação do alimento e também sobre a matéria-prima, ambiente, processo, pessoas diretamente envolvidas, estocagem, transporte e distribuição. Assim foi desenvolvido esse sistema (SENAI, 2001).

O Sistema APPCC e seus pré-requisitos são as ferramentas utilizadas pelas indústrias de alimentos para controlar os perigos à saúde do consumidor e conferir qualidade aos seus produtos (SILVA JR, 2001).

Sua filosofia baseia-se na identificação sistemática, na análise e no controle de risco nas diversas etapas de um processo (SENAI, 2001). 
Sua aplicação inclui aspectos que vão desde a produção até, a exposição à venda dos produtos alimentícios consumo. Envolve a produção primária, as indústrias, os consumidores, os inspetores/fiscalizadores, os importadores/exportadores e os fornecedores de produtos e serviços de qualquer natureza que se relacione com a segurança do produto como: embalagens, agentes de limpeza e desinfecção, fornecedores de equipamentos, agência de controle de insetos e roedores, manipuladores de alimentos, trabalhadores rurais e outro de forma a identificar, caracterizar, adotar medidas preventivas de controle e efetivamente controlar os perigos possíveis dos produtos alimentícios (SILVA JR, 1995).

Etapas para a implantação dessa ferramenta de segurança alimentar requerem preparo do sistema APPCC. De principio faz-se uma reunião com os membros da equipe APPCC, onde é feita a descrição do produto, identificação do seu uso intencional, construção do diagrama do fluxo e verificação do mesmo e então a etapa final que é a identificação dos perigos em potencial. Para a execução desta última etapa são seguidos sete princípios, que são: relaciona-los com cada etapa operacional e determinação das medidas de controle dos perigos, determinação dos pontos críticos de controle (PCC), estabelecimento dos limites críticos para cada PCC, estabelecimento dos procedimentos de monitoramento, estabelecimento dos procedimentos de ações corretivas, estabelecimento dos procedimentos de registro e estabelecimento dos procedimentos de verificação (SILVA JR, 1995).

Este sistema permite identificar, avaliar e controlar perigos que comprometam a sanidade dos alimentos. Os pontos críticos são situações ou locais onde os perigos estão presentes com riscos à saúde. A cada ponto crítico corresponde um controle, a cada controle atribui-se um critério que deve ser monitorado e quando o desvio observado pode ser corrigido durante o processo, define-se como um PCC (ponto crítico de controle) (SILVA JR,1995). 
Os pontos críticos são situações ou locais onde os perigos estão presentes com riscos à saúde. A cada ponto crítico corresponde um controle, a cada controle atribui-se um critério que deve ser monitorado e quando o desvio observado pode ser corrigido durante o processo, define-se como um PCC (CARVALHO, 2003).

Uma vez identificados os riscos, durante a elaboração de um alimento, torna-se possível controlar os pontos onde os riscos podem surgir. Essa metodologia se estende ao longo de toda a cadeia alimentar, incluindo a obtenção de matéria-prima, processamento, transporte, comercialização e sua utilização final pelo consumidor (CARVALHO, 2003).

O Sistema APPCC e seus pré-requisitos são as ferramentas utilizadas pelas indústrias de alimentos para controlar os perigos à saúde do consumidor e conferir qualidade aos seus produtos (CARVALHO, 2003).

\subsubsection{Legislação}

Visando melhorar as condições higiênico-sanitárias, a Secretaria de Vigilância Sanitária do Ministério da Saúde publicou através da lei 8.080 - de 1909-90, que estabelece a necessidade da melhoria da qualidade de vida decorrente da utilização de bens, serviços e ambientes oferecidos à população na área de alimentos.

Para melhorar as condições operacionais na preparação de alimentos e adequar a ação da Vigilância Sanitária, o Ministério da Saúde publicou a Portaria N 1428 de 26/11/93, recomenda a elaboração de um Manual de Boas Práticas de Manipulação de Alimentos, baseado nas publicações técnicas da Sociedade Brasileira de Ciência e Tecnologia de Alimentos, Organização Mundial de Saúde e Codex Alimentarius. Em agosto de 1997 foi publicada a Portaria Ministerial № 326 de 30/07/97, que define as condições técnicas para a elaboração do manual de boas práticas. De acordo com estas recomendações, no dia 12/03/99 o Centro de 
Vigilância Sanitária do Estado de São Paulo publicou a Portaria CVS-6 de 10/03/99, que consiste em um "Regulamento Técnico sobre os Parâmetros e Critérios" para orientar as ações da Vigilância Sanitária e as operações de controle para os estabelecimentos produtores e prestadores de serviços de alimentação (SILVA JR, 2001).

No Brasil, por força do disposto no Capítulo $\vee$, do artigo n. ${ }^{\circ} 28$ do DecretoLei n. ${ }^{\circ}$ 986/69, foram fixadas normas gerais de higiene (Resolução n. ${ }^{\circ}$ 33/77), para assegurar as condições da pureza necessárias aos alimentos destinados ao consumo humano, pela Comissão Nacional de Normas e Padrões para Alimentos, CNNPA.

A Lei n. ${ }^{\circ}$ 8.078/90 trata dos Direitos do Consumidor e dispõe em seu art. $8^{\circ}$ que "os produtos e serviços colocados no mercado de consumo não acarretarão riscos à saúde ou segurança dos consumidores". Define como objetivo do Sistema Único de Saúde, em seu art. $5^{\circ}$, item VIII, a fiscalização e a inspeção de alimentos, água e bebidas para consumo humano. A Portaria Ministerial n. ${ }^{\circ}$ 1.428/93, determina em seu artigo $2^{\circ}$ "que os estabelecimentos relacionados à área de alimentos adotem, sob responsabilidade técnica, as suas próprias Boas Práticas de Produção e/ou Prestação de Serviços, seus Programas de Qualidade , e atendam aos PIQ para Produtos e Serviços na Área de alimentos. A Portaria $\mathrm{n}^{\circ}$ 326-SVS/MS DE 1997, estabelece "Regulamento Técnica sobre as Condições Higiênico- Sanitárias e de Boas Práticas de Fabricação para estabelecimentos de Produtos Industrializados de Alimentos (FILHO, 2002).

\subsubsection{Código de Defesa do Consumidor}

A Lei $n^{\circ}$ 8.078, de 11 de setembro de 1990, diz que é direito básico do consumidor ter proteção da vida, saúde e segurança contra os riscos provocados por práticas no fornecimento de produtos e serviços considerados perigosos ou nocivos. 
O artigo $8^{\circ}$ revela que os produtos e serviços colocados no mercado de consumo não acarretarão riscos à saúde ou segurança dos consumidores, exceto os considerados normais e previsíveis em decorrência de sua natureza e fruição, obrigando-se os fornecedores, em qualquer hipótese, a dar as informações necessárias e adequadas a seu respeito.

\subsection{MERCADO VAREJISTA}

Atualmente a comodidade, a segurança, a vasta variedade de produtos oferecidos, o preço e a higiene, direcionam os consumidores a fazer suas compras preferencialmente em grandes mercados. Conseqüentemente, para atender em melhor sua clientela, tais empresas elaboram produtos cada vez mais práticos e de fácil consumo. A exemplo podem ser citados os diferentes tipos de carnes cortadas, fatiadas, moídas, porcionadas e embaladas indívialmente, como a carne bovina (LIMA, 2001).

Entretanto, a oferta desses produtos, requer uma maior manipulação, que pode oferecer risco á saúde do consumidor, pela possibilidade de haver contaminação, especialmente, de natureza higiênico-sanitária (LIMA, 2001).

Pesquisa realizada em grandes redes de supermercados de São Paulo, revelou que, de maneira geral, produtos com este tipo de elaboração não atendem aos padrões microbiológicos exigidos pela legislação, o que demonstra condições higiênicas insatisfatórias na manipulação dos alimentos e também falhas nas temperaturas de armazenagem (LIMA, 2001).

A melhoria das condições higiênico-sanitárias e tecnológicas em supermercados possibilita o atendimento às exigências legais dos consumidores, que passam a avaliar diferentemente o cuidado que a empresa dispensa aos procedimentos operacionais (GONÇALVES et al., 2002).

A presença de um responsável técnico proporciona a obtenção de um 
melhor controle dos processos operacionais, assim permite tomar decisões sobre o destino final de produtos que não satisfaçam aos requisitos legais, (BRASIL, 1976; BRASIL, 1977).

Em Belo Horizonte, a portaria de $n^{\circ}$ 018/2001 da Vigilância Sanitária, obriga que o responsável técnico pela área de Produtos de Origem Animal tenha como formação básica a medicina veterinária, em nível superior. A literatura relata um estudo de casos que mostra o aumento do padrão de qualidade em produtos de origem animal, em supermercados;quando os procedimentos são monitorados por tais profissionais. O diferencial, supostamente, se deve ao conhecimento científico aliado a experiência prática (GONÇALVES et al., 2002).

\subsection{CARACTERÍSTICAS E POSSÍVEIS ALTERAÇÕES DA CARNE BOVINA "IN NATURA"}

A carne é o meio de cultura ideal para o desenvolvimento microbiano por apresentar elevada atividade de água (aw) e ser rica em substâncias nitrogenadas, em minerais e em fatores de crescimento. Seu pH (5.6) é favorável a maioria dos microrganismos, cujo desenvolvimento dependerá das condições de abate, estresse do animal e higiene durante a manipulação. Os tipos mais comuns de deterioração são provocados por bactérias, leveduras ou bolores; que em condições de aerobiose modificam a cor, sabor, aroma e gordura presente na carne (PIERSON \& CORLETT JR., 1992).

A superfície e a umidade da superfície da carne e do ar podem oferecer o crescimento de microrganismos causadores da mucosidade ou limo superficial (Tabelas 2 e 3). 
Tabela 2: Principais microrganismos encontrados em alimentos (bactérias)

\begin{tabular}{|c|c|}
\hline BACTÉRIAS & PREDOMINÂNCIA \\
\hline \multicolumn{2}{|l|}{ Coliformes totais } \\
\hline $\begin{array}{l}\text { Enterobacter sp, Klebsiella sp, } \\
\text { Citrobacter sp. }\end{array}$ & $\begin{array}{l}\text { Fezes do homem e animais, vegetais, } \\
\text { solo, águas residuais }\end{array}$ \\
\hline \multicolumn{2}{|l|}{ Coliformes Fecais } \\
\hline Escherichia colt. & $\begin{array}{l}\text { Fezes do homem e animais (indicador } \\
\text { de poluição fecal) }\end{array}$ \\
\hline \multicolumn{2}{|l|}{ Outras Enterobactérias } \\
\hline $\begin{array}{l}\text { Proteus sp, Edwardsiella sp, Serratia } \\
\text { sp, Salmonella sp, Shigella sp, } \\
\text { Yersinia sp, outras. }\end{array}$ & $\begin{array}{l}\text { Fezes do homem e animais, vegetais e } \\
\text { água }\end{array}$ \\
\hline $\begin{array}{l}\text { Bacilos Gram negativos não entéricos } \\
\text { Pseudonomas sp, Aeromonas sp, } \\
\text { Alcaligenes sp, Choromobacterium } \\
\text { sp, Acinetobacter sp, Brucella sp e } \\
\text { outras. }\end{array}$ & Vegetais, solo, água, frutas, leite \\
\hline \multicolumn{2}{|l|}{ Streptococus sp } \\
\hline $\begin{array}{l}\text { Grupo enterococos. } \\
\text { Grupo oral. } \\
\text { Grupo piogênico }\end{array}$ & $\begin{array}{l}\text { Fezes do homem e animais, ambientes } \\
\text { em geral. } \\
\text { Região bucal } \\
\text { Região faríngea }\end{array}$ \\
\hline \multicolumn{2}{|l|}{ Staphylococcus sp } \\
\hline Staphylococcus aureus. & Região nasal \\
\hline $\begin{array}{l}\text { Staphylococcus epidermidis e outros. } \\
\text { Bacillus }\end{array}$ & Região da pele e ambiente. \\
\hline Bacillus cereus. & Cereais, grãos, farinhas \\
\hline Bacillus subtilis e outros. & Ambiente em geral \\
\hline \multicolumn{2}{|l|}{ Clostridium Sulfito Redutores } \\
\hline Clostridium perfrigens. & $\begin{array}{l}\text { Solo, água, vegetais e fezes do homem } \\
\text { e animais. }\end{array}$ \\
\hline \multicolumn{2}{|r|}{ e } \\
\hline $\begin{array}{l}\text { Vibrio parahaemolyticus } \\
\text { Campylobacter }\end{array}$ & Peixes, mariscos e animais aquáticos \\
\hline Campylobacter jejuni e outras. & Aves (carcaças), leite, carne suína. \\
\hline
\end{tabular}
Fonte: SILVA JR., 1995.

Os pigmentos de hemoglobina e mioglobina da carne são indicadores de qualidade. A exposição da carne a variadas condições ambientais (calor, acidez e agentes químicos) favorecem a oxidação do ferro presente nestes pigmentos, 
alterando a cor. Estes pigmentos além de indicadores de frescor, são também indicadores de alterações físicas, químicas ou bacterianas, (PRICE \& SCHWEIGERT. 1994).

A cor vermelha da carne pode adquirir tons de verde, marrom ou cinza decorrentes de ação dos oxidantes, gás sulfídrico (H2S) e peróxidos (H2O2), produzidos por bactérias. Suas causas são, respectivamente: carnes e derivados embalados a vácuo expostos ar, ou crescimento de microrganismos no centro da peça; carnes vermelhas frescas embaladas a vácuo ou embalagem impermeável a troca gasosas e conservadas em temperatura entre $1^{\circ}$ e $5^{\circ} \mathrm{C}$ (FRANCO \& LANDGRAF. 1996)

As principais alterações da carne provocadas por mofos são, o aspecto pegajoso na superfície do produto e o desenvolvimento micelar causados por espécies do gênero Mucor (M. racebiosus, M.lusitanicus), Tamnidium (T. chaeto cladioides, T. elegans) e Rhizopus (FRAZIER \& WESTHOFF 1993). O acondicionamento sob temperaturas próximas ao congelamento pode favorecer a formação de micélio cotonoso, sem esporulação e de cor branca, (FRANCO \& LANDGRAF.1996).

Tabela 3: Principais microrganismos encontrados em alimentos (fungos)

\begin{tabular}{ll}
\hline \multicolumn{1}{c}{ FUNGOS } & \multicolumn{1}{c}{ PREDOMINÂNCIA } \\
\hline Bolores & Ambiente \\
Penicillium sp & Ambiente (alergia) \\
Alternaria sp & Ambiente e pão \\
Rhizopus sp & Vegetais \\
Fuzarium sp & Ambiente \\
Aspergillus niger & Amendoim, castanha, nozes \\
Aspergillus flavus & \\
Leveduras & Micoses da pele e mucosa e ambiente \\
Cândida sp, Rhodoturula sp, & em geral \\
Torulopsis sp &
\end{tabular}

Fonte: SILVA JR., 1995. 
Putrefação significa decomposição anaeróbia de proteína com produção de compostos de aroma desagradáveis como H2S, indol, escatol, putrecsina, cadaverina e outros. O Clostridium é o causador mais comum desse tipo de deterioração, embora bactérias aeróbias facultativas, (Clostridium butíricos e coliformes), possam contribuir também para a acidificação. Bactérias lácticas estão presentes em quase todos tipos de produtos cárneos, crescendo também em temperatura de refrigeração. Esse desenvolvimento é desejável (fermentação láctica) na superfície ou interior da peça, porém a produção de ácido láctico e outros ácidos em excesso pode originar coloração esverdeada no produto, (FRAZIER e WESTHOFF. 1993).

\subsection{MÉTODO DE CONSERVAÇÃO PELO FRIO}

O uso do frio, associado a outras técnicas de conservação, é largamente utilizado por causa da manutenção da qualidade do produto a ser conservado (MENDES, 2001).

O processo de resfriamento das carnes inicia-se logo após o abate, quando as carcaças são submetidas a $15^{\circ} \mathrm{C}$, em câmara especial, onde começa a "cadeia de frio" e esta somente deve ser interrompida quando se for aplicar outro método de conservação, como cocção (MENDES, 2001).

A refrigeração retarda a atividade microbiana, (enzimática e as reações químicas), mas não mata as bactérias existentes; é um processo bacteriostático (CHESCA et al, 2001).

Utiliza temperaturas um pouco acima do ponto de congelação. Pode ser indicada como meio de conservação básica ou como conservação temporária. $A$ temperatura de refrigeração é relevante na conservação do produto, assim sendo, a $5^{\circ} \mathrm{C}$, um produto será conservado por 5 dias; a $15^{\circ} \mathrm{C}$ poderá ser deteriorado em um dia, assim por diante como mostra a tabela 3(GAVA, 1984). 


\subsection{EFEITO DA SEGURANÇA ALIMENTAR À SAÚDE DO CONSUMIDOR}

Qualidade pode ser definida como o conjunto de características que irão diferenciar na aceitabilidade de um alimento. Os fatores de qualidade detectados pelos nossos órgãos do sentido podem ser divididos em três categorias: aparência, textura e "flavor". O consumidor, ao escolher um determinado alimento, o faz tendo em vista, respectivamente, o preço, aparência, sabor e valor nutritivo, (GAVA 1984).

O controle de qualidade assegura, ao industrial, a fabricação de alimentos de excelente padrão e proporciona, ao consumidor, um produto em condições a cumprir sua finalidade de alimentar e nutrir.

O prestígio do produto alimentício se firma pela qualidade que apresenta, por seu aspecto, pela idoneidade de seu fabricante e, sobretudo pela uniformidade de seu padrão. A posição de estabilidade técnica do produto e sua conseqüente aceitabilidade, só poderão ser obtidas pela instituição do regime de controle de qualidade (EVANGELISTA 2001).

Dentre os aspectos de Segurança Alimentar, a produção de alimentos seguros tem sido uma exigência mundial, especialmente nos últimos anos, com a ocorrência de toxinfecção em países desenvolvidos e não desenvolvidos, mais especificamente em produtos como as carnes (EVANGELISTA 2001).

A presença de um responsável técnico em supermercados; estabelecimentos mais procurados e freqüentados atualmente pelos consumidores, com a responsabilidade de manter a qualidade, inocuidade e higiene passam para o consumidor e cliente a segurança e confiança de que o produto a ser consumido é de boa procedência e foi manipulado em condições adequadas, não colocando em risco sua saúde e a de sua família (EVANGELISTA, 2001). 


\section{MATERIAL E MÉTODOS}

Para elaboração deste trabalho foi utilizada uma abordagem do tipo Pesquisa Exploratória que tem como objetivo proporcionar maiores informações sobre o assunto que será investigado e facilitar a delimitação do tema e das hipóteses ou descobrir um novo tipo de enfoque para o assunto.

Uma pesquisa é a realização de uma investigação planejada, desenvolvida e redigida utilizando normas da metodologia, padronizando consagrada pela ciência.

\subsection{Material}

Foram pesquisadas 40 amostras de carnes fracionadas bovina, embaladas e expostas em mercado varejista, estas amostras se encontravam em exposição para os clientes em balcões refrigerados próximos a seção de açougue das respectivas lojas.

Foram analisadas amostras de 5 mercados varejistas - A, B, C, D \& E localizados no Plano Piloto do Distrito Federal pertencentes redes diferentes de administração e freqüentados, especialmente, por pessoas de classe social média-alta.

Foram realizadas quatro visitas, duas no mês de fevereiro e duas no mês de março de 2006 em dois dias consecutivos e em horários variados em cada um dos mercados, a fim de evitar o viés de avaliar o mesmo grupo de funcionários e o tipo de produto oferecido. As visitas tiveram em média vinte minutos de duração em cada loja.

\subsection{Método}

Para coletar as informações necessárias foi utilizada a Ficha de Análise da Qualidade da Carne Bovina desenvolvida de acordo com as exigências dos órgãos competentes, como a Vigilância Sanitária e a Secretaria de Agricultura. Os 
itens contemplados corresponderam aos atributos de qualidade para o parâmetro organoléptico das carnes bovinas fracionadas, embaladas e expostas no mercado varejista. Além disso, fez-se uma avaliação da temperatura de exposição dos produtos, utilizando-se um termômetro digital RayteK, sem contato,,,apropriado para conferir temperaturas de alimentos, graduado em graus Celcius, $\mathrm{C}^{\circ}$.

A adequação a tais atributos foi avaliada como conformidade (C) e não conformidade (NC). As conformidades se referiam a cor vermelho brilhante, odor característico, aspecto não pegajoso e temperatura igual ou menor a $7^{\circ} \mathrm{C}$; e as inconformidade se referiam a qualquer desacordo com as conformidades. 


\section{RESULTADOS E DISCUSSÃO}

As tabelas 4, 5, 6, e 7 apresentam os dados obtidos referentes a conformidade e não conformidades aos parâmetros sensórias e temperatura de exposição nas visita 1, 2, 3 e 4 aos mercados A, B, C, D \& E. das bandejas de carne bovina expostas à comercialização. A tabela 5 apresenta o percentual de conformidade e não conformidade a tais parâmetros da cada loja visitada.

Tabela 4: Conformidade e não conformidade aos parâmetros sensórias e temperatura de exposição - Visita 1

\begin{tabular}{|c|c|c|c|c|}
\hline & Temperatura & Cor & Odor & Aspecto \\
\hline A & NC & C & C & C \\
\hline B & C & NC & C & C \\
\hline C & NC & NC & C & NC \\
\hline D & C & C & C & C \\
\hline E & NC & C & C & C \\
\hline
\end{tabular}

Tabela 5: Conformidade e não conformidade aos parâmetros sensórias e temperatura de exposição - Visita 2

\begin{tabular}{|c|c|c|c|c|}
\hline & Temperatura & Cor & Odor & Aspecto \\
\hline A & C & C & C & C \\
\hline B & NC & NC & C & C \\
\hline C & C & C & NC & NC \\
\hline D & NC & NC & C & C \\
\hline E & NC & C & C & C \\
\hline
\end{tabular}

Tabela 6: Conformidade e não conformidade aos parâmetros sensórias e temperatura de exposição - Visita 3

\begin{tabular}{|c|c|c|c|c|}
\hline & Temperatura & Cor & Odor & Aspecto \\
\hline A & C & NC & C & C \\
\hline B & NC & C & C & NC \\
\hline C & NC & C & C & C \\
\hline D & C & NC & C & C \\
\hline E & NC & NC & NC & NC \\
\hline
\end{tabular}

Tabela 7: Conformidade e não conformidade aos parâmetros sensórias e temperatura de exposição - Visita 4

\begin{tabular}{|l|l|l|l|}
\hline Temperatura & Cor & Odor & Aspecto \\
\hline
\end{tabular} 


\begin{tabular}{|c|c|c|c|c|}
\hline $\mathrm{A}$ & $\mathrm{NC}$ & $\mathrm{NC}$ & $\mathrm{C}$ & $\mathrm{NC}$ \\
\hline $\mathrm{B}$ & $\mathrm{C}$ & $\mathrm{NC}$ & $\mathrm{C}$ & $\mathrm{C}$ \\
\hline $\mathrm{C}$ & $\mathrm{NC}$ & $\mathrm{C}$ & $\mathrm{C}$ & $\mathrm{C}$ \\
\hline $\mathrm{D}$ & $\mathrm{C}$ & $\mathrm{C}$ & $\mathrm{C}$ & $\mathrm{C}$ \\
\hline $\mathrm{E}$ & $\mathrm{C}$ & $\mathrm{NC}$ & $\mathrm{C}$ & $\mathrm{C}$ \\
\hline
\end{tabular}

Com relação aos resultados obtidos verifica-se que o mercado $A$ demonstrou inconformidade na temperatura em 50\% das visitas; ao parâmetro cor em $50 \%$ das visitas. Não apresentou inconformidades em relação ao odor e ao aspecto em $25 \%$ das visitas.

Por outro lado, o mercado B demonstrou ter não conformidade com relação à temperatura em $50 \%$ das visitas. Para os parâmetros cor e aspecto as inconformidade foi de $75 \%$ e $25 \%$ das visitas, respectivamente.

O mercado $C$ demonstrou não conformidade para o parâmetro temperatura em $75 \%$ das visitas. Para cor em 25\% das visitas; odor em $25 \%$ das visitas e para aspecto em 50\% das visitas. Para o mercado D a inconformidade foi de $25 \%$ e $50 \%$ para temperatura e cor, não apresentou inconformidades para os itens odor e apecto. O mercado $\mathrm{E}$ demonstrou ter não conformidade para os itens temperatura em $75 \%$ das visitas, cor $50 \%$, odor $25 \%$ e aspecto $25 \%$.

Tabela 8: Resultado das Não Conformidades

\begin{tabular}{|c|c|c|c|c|}
\hline & Tempreatura & Cor & Odor & Aspecto \\
\hline A & $50 \%$ & $50 \%$ & - & $25 \%$ \\
\hline B & $50 \%$ & $75 \%$ & - & $25 \%$ \\
\hline C & $75 \%$ & $25 \%$ & $25 \%$ & $50 \%$ \\
\hline D & $25 \%$ & $50 \%$ & - & - \\
\hline E & $75 \%$ & $50 \%$ & $25 \%$ & $25 \%$ \\
\hline
\end{tabular}

Os resultados sugerem que a temperatura inadequada nem sempre significa o não funcionamento do refrigerador; é possível que se deva ao tipo de balcão expositor, muito aberto e trocando calor com o ambiente; pela forma de exposição dos produtos no balcão, que pode interferir na propagação do frio; pela 
temperatura externa elevada denter os vários fatores que podem interferir na temperatura dos produtos.

Foram encontrados resultados que indicam 0 uso de adequada temperatura, porém inadequação quanto à cor ou inadequação na temperatura e cor conforme, conformidade na temperatura e não conformidade do aspecto; que sugerem quebra na cadeia do processo de conservação antes mesmo do produto ser exposto à venda.

Além disso, a utilização de equipamentos e utensílios contaminados como facas e bancadas, bem como a não higienização adequada das mãos interferem diretamente na qualidade dos produtos oferecidos aos consumidores que acabam consumindo produtos contaminados ou até mesmo em processo de deterioração.

Os pigmentos de hemoglobina e mioglobina da carne são indicadores de qualidade. Estes pigmentos indicam além de frescor, alterações físicas, químicas ou bacterianas (PRINCE \& SCHWEIGERT. 19994).

A cor vermelha da carne pode adquirir cores de tons de verde, marrom e cinza decorrente de ação dos oxidantes, gás sulfídrico (H2S) e peróxidos $(\mathrm{H} 2 \mathrm{O} 2)$, produzidos por bactérias (FRANCO \& LNDGRAF. 1996).

Bactérias lácticas estão presentes em quase todos tipos de produtos cárneos, crescendo também em temperatura de refrigeração, porém a produção em excesso de ácido láctico e outros ácidos podem originar coloração esverdeada no produto (FRAZIER \& WESTHOFF. 1993).

A cor, odor e aspecto demonstram a qualidade dos produtos cárneos e a temperatura um dos métodos de conservação mais utilizados, porém sem boas práticas de fabricação e manipulação, a baixa temperatura não consegue manter a carne em condição apropriada para o consumo.

Recomenda-se a orientação e o treinamento dos funcionários a fim de acrescer conhecimento sobre a cadeia de frios bem como o mecanismo das bactérias prejudiciais a saúde humana. 


\section{CONCLUSÕES}

Todos os mercados apresentaram inconformidade com relação a temperaturas inadequadas de exposição, com relação à cor das carnes bovinas em baladas; $50 \%$ dos estabelecimentos apresentaram inconformidade com relação ao odor e $75 \%$ dos mercados tiveram inconformidade com relação ao aspecto. Os mercados $\mathrm{C}$ e $\mathrm{E}$ foram os estabelecimentos que mais apresentaram inconformidades em igual proporção. 


\section{REFERÊNCIAS BIBLIOGRÁFICAS}

BORGES, J. T. S.; FREITAS, A. S. Aplicação do sistema analysis and critical control points (HACCP) no processamento de carne bovina fresca. Boletim Centro de Pesquisa de Processamento de Alimentos, Curitiba, v.20, n.1, p.1-18. jan./jun., 2002. Disponível em: <http://calvados.c3sl.ufpr.br/ojs2/index.php/ alimentos/article/view/1131/932>.

BRASIL. Lei 8080/90, de 19 de setembro de 1990. Portaria Ministério da Saúde no 1428 de 26 de novembro de 1993. Portaria Ministério da Saúde 326 de 30 de Julho de 1997.

BRASIL. Código de Defesa do Consumidor. Lei 8078, de 11 de setembro de 1990.

BRASIL. Ministério da Saúde. Secretaria de Vigilância Sanitária. Portaria no 326 , de 30 de julho de 1997. Diário Oficial, Brasília, DF, 01 ago. 1997.

BRASIL. Portaria 1428/93. ANVISA Portaria n 1.428/MS, de 26 de nov. de 1993.

CARVALHO, H. H. C. Seminário de fiscalização manual de boas práticas: uma abordagem prática. Revista Padaria 2000, São Paulo, v. 7, n. 37, p. 130, mar./abr., 2000.

CHESCA, A. C. et al. Levantamento das temperaturas de armazenamento de carnes, em açougues e supermercados de Uberaba, MG. Revista Higiene Alimentar, São Paulo, v.15, n.81, p.51-55, maio, 2001.

EVANGELISTA, J. Tecnologia de alimentos. 2.ed. Rio de Janeiro: Atheneu, 2000. $652 \mathrm{p}$.

FILHO, J. B. L. A Evolução da legislação sobre as boas práticas de produção e prestação de serviços na área de alimentos/alimentação. mar./abr. 2002. Disponível em: <http://www.nutricaoempauta.com.br.> Acesso em: 17 fev. 2006.

FRANCO, B. D. G. de M.; LANDGRAF, M. Microbiologia dos alimentos. São Paulo: Atheneu, 1996. 182p.

FRAZIER, W. C.; WESTHOFF, D. C. Microbiologia dos alimentos. São Paulo: Atheneu, 1993. 681p.

GAVA, A. J. Princípios de tecnologia de alimentos. São Paulo: Nobel. 1984. 284 p.

GOÉS, J. A. W. et al. Capacitação dos manipuladores de alimentos e a qualidade da alimentação servida. Revista Higiene Alimentar, São Paulo, v.15, n. 82, p. 2026, mar. 2001. 
GONÇALVES, J.M. et al. Veterinária e zootecnia em Minas Gerais. ano 17, n. 76, nov./dez. 2002.

HARES, L.F. O que são as boas práticas de fabricação e manipulação de alimentos?. Revista Padaria 2000, São Paulo, v. 7, n. 37, p. 130, mar./abr. 2000.

JORNAL DA USP. São Paulo, ano 18, n. 627, p.13-19, jan. 2003.

LEITÃO, M. F. F. Controle microbiológico da qualidade no processamento industrial de bovinos. Ciência e Tecnologia da Carne/Instituto de Tecnologia e Alimentos, Campinas, p. 89-92, 1994.

LIMA, C. L. Manual prático de controle de qualidade em supermercados. 1 ed. São Paulo: Varela, 2001. 17p.

LOURENÇO, A. E. P. Enteroparasitoses em manipuladores de alimentos de hospitais da cidade de Niterói, RJ, Brasil. Revista Higiene Alimentar, São Paulo, v.16, n. 97, p.16-21, jun. 2002.

MANCIO, A.B. Carne segura. 2001. Disponível em: <http:// www.boidecorte. com.br>. Acesso em: 17 fev. 2006.

MENDES, A. C. R. Condições de comercialização de cortes cárneos em supermercados da cidade de Salvador, BA. Revista Higiene Alimentar, São Paulo, v.15, n. 82, abr. 2001.

PANETTA, J. C. Prevalência e controle de enfermidades humanas transmitidas pela ingestão de carne bovina. Ciência e Tecnologia da Carne/Instituto de Tecnologia e Alimentos, Campinas, p.14-17, 1994.

PARDI, M. C. et al. Ciência, Higiene e Tecnologia da Carne. 2. ed. Goiânia: CEGRAF - UFG/ Niterói: EDUFF, 586p., v. 1, 1995.

PIERSON, M.; CORLETT JR, D. A. HACCP: principles and applicatons. New York: Chapman \& Hall, 1992. 212p.

PRINCE, J. F.; SCHWEIHERT, B. S. Ciência de la carne y los productos carnicos. 2. ed. Zaragosa: Acribia, 1994. 581p.

SENAI. Guia para implantação de boas práticas de sistema APPCC. Rio de Janeiro: SENAC, 2001. 229p. 
SECRETARIA DA SAÚDE DO ESTADO DE SÃO PAULO. Portaria CVS n 6 de 10 de março de 1999.

SECRETARIA DA SAÚDE DO ESTADO DE SÃO PAULO. Portaria CVS n 30 de 31 de janeiro de 1994.

SILVA JR, E. A. Boas práticas e procedimentos padrões de operacional - PPHO. Segurança Alimentar: controle higiênico sanitário. São Paulo, abr. 2001. Disponível em: <http:// www.nutricaoempauta.com.br>. Acesso em: 17 fev. 2006.

SNIJDERS, J. M. A. Livestock Production Sciense, v. 76, set. 2002.

SNIJDERS, J.M.A. Prevention of human diseases by an integrated quality control system. Livestock Productions Science, v. 76, n. 3, p. 203-206, set. 2002.

UNIMEV. Apostila do curso de formação profissional em vigilância sanitária. Cooperativa dos médicos veterinários do Rio de Janeiro, 2003. 


\section{ANEXOS}

\section{Anexo 01: Portaria cvs 6}

Ao que se refere às instalações sanitárias: devem existir banheiros separados por sexo, constituído de gabinete sanitário, pia e mictório para cada 20 funcionários, dispostos de bacia com tampa, papel higiênico, lixeira com tampa acionada por pedal, mictórios com descarga, pias para lavar as mãos, sabonete líquido ou sabão anti-séptico, toalha de papel, de cor clara, não reciclado; as instalações sanitárias devem ser bem iluminadas, paredes e piso de cores claras, de material liso, resistente e impermeável, portas com molas, ventilação adequada com janelas teladas. Não devem se comunicar diretamente com a área de manipulação de alimentos ou refeitórios. Os vestiários devem ser separados por sexo, devendo possuir armários individuais e chuveiro para cada 20 funcionários, com paredes e pisos de cores claras, material liso, resistente e impermeável, portas com molas, ventilação adequada e janelas teladas.

Quanto ao destino adequado de resíduos estes devem estar dispostos adequadamente em recipientes com tampas, constituídos de material de fácil higiene. O lixo fora da cozinha deve ficar em local fechado, isento de moscas, roedores e outros animais. O lixo não deve sair da cozinha pelo mesmo local onde entram as matérias primas. Na total impossibilidade de áreas distintas, determinar horários diferenciados. O lixo deve estar devidamente adicionado, de modo que não represente riscos de contaminação.

O dimensionamento dos equipamentos deve ter relacionamento direto com o volume de produção, tipos de produtos ou padrão de cardápio e sistema de distribuição/venda. Os equipamentos devem ser dotados de superfície lisa, de fácil limpeza e desinfecção, bem conservados, com pinturas claras, sem gotejamento de graxa, acúmulo de gelo e com manutenção constante. Utensílios de preparação suficientes, bem conservados, sem crostas, limpos e sem resíduos. Armazenados, após a lavagem e desinfecção, de forma ordenada e protegidos contra sujidades e insetos. 
No que diz respeito ao pessoal na área de produção/manipulação e venda, os funcionários devem ter a saúde clínica controlada, exigida pela Vigilância Sanitária, que objetiva a saúde do trabalhador e a sua condição para estar apto para o trabalho, não podendo ser portador aparente ou inaparente de doenças infecciosas ou parasitárias. Para isso devem ser realizados os exames médicos admissionais, periódicos, dando ênfase aos parâmetros preconizados neste regulamento, acompanhados das análises laboratoriais como: hemograma, coprocultura, coproparasitológico e VDRL (para pesquisa de sífilis), devendo ser realizadas outras análises de acordo com avaliação médica. A periodicidade dos exames médico-laboratoriais deve ser anual. Dependendo das ocorrências endêmicas de certas doenças, a periodicidade pode ser reduzida de acordo com os serviços de Vigilância Sanitária e Epidemiológica locais. Qualquer tipo de controle de saúde do trabalhador que contemple o controle de saúde clínico e desde que comprovado com os respectivos laudos, estará de acordo com este Regulamento, não sendo necessária, neste caso, a Carteira de Saúde. Não devem manipular alimentos, os funcionários que apresentarem feridas, lesões, chagas ou cortes nas mãos e braços, ou gastrenterites agudas ou crônicas (diarréia ou disenteria), assim como, os que estiverem acometidos de infecções pulmonares ou faringites. A gerência deve garantir que os funcionários nessas situações, sejam afastados para outras atividades, sem prejuízo de qualquer natureza. Os uniformes devem ser completos, de cor clara, bem conservados e limpos e com troca diária, e de utilização somente nas dependências internas do estabelecimento; os sapatos devem ser fechados, em boas condições de higiene e conservação. Devem ser utilizadas meias; o uso de avental plástico deve ser restrito às atividades onde há grande quantidade de água, não devendo ser utilizado próximo ao calor; não utilizar panos ou sacos plásticos para proteção do uniforme; não carregar no uniforme: canetas, lápis, batons, escovinhas, cigarros, isqueiros, relógios e outros adornos e nenhuma peça do uniforme deve ser lavada dentro da cozinha.

A higiene pessoal é a parte de maior importância desta portaria. Devem ser levados em consideração a prática de estética e asseio onde são considerados os 
banhos diários, cabelos protegidos, barba feita diariamente e bigode aparado, unhas curtas, limpas, sem esmalte ou base, uso de desodorante inodoro ou suave sem utilização de perfumes, maquiagem leve, não utilização de adornos (colares, amuletos, pulseiras ou fitas, brincos, relógio e anéis, inclusive alianças).

A higiene das mãos deve ser praticada sempre que chegar ao trabalho, utilizar os sanitários, tossir, espirrar ou assoar o nariz, usar esfregões, panos ou materiais de limpeza, fumar, recolher lixo e outros resíduos, tocar em sacarias, caixas, garrafas e sapatos, tocar em alimentos não higienizados ou crus, pegar em dinheiro, houver interrupção do serviço, iniciar um novo serviço, tocar em utensílios higienizados e colocar luvas. A técnica de higienização das mãos iniciase com o umedecer as mãos e antebraços com água, lavar com sabonete líquido, neutro, inodoro. Pode ser utilizado sabonete líquido anti-séptico, neste caso, massagear as mãos e antebraços por pelo menos 1 minuto, enxaguar bem as mãos e antebraços, secar as mãos com papel toalha descartável não reciclado, ar quente ou qualquer outro procedimento apropriado. Aplicar anti-séptico, deixando secar naturalmente o ar, quando não utilizado sabonete anti-séptico, este pode ser aplicado com as mãos úmidas.Os anti-sépticos permitidos são: álcool $70 \%$, soluções iodadas, iodóforo, clorohexidina ou outros produtos aprovados pelo Ministério da Saúde para esta finalidade.

Não fazem parte da higiene operacional e não são permitidos durante a manipulação dos alimentos falar, cantar, assobiar, tossir, espirrar, cuspir, fumar, mascar goma, palito, fósforo ou similares, chupar balas, comer, experimentar alimentos com as mãos, tocar o corpo, assoar o nariz, colocar o dedo no nariz ou ouvido, mexer no cabelo ou pentear-se, enxugar o suor com as mãos, panos ou qualquer peça da vestimenta, manipular dinheiro, tocar maçanetas com as mãos sujas, fazer uso de utensílios e equipamentos sujos, trabalhar diretamente com alimento quando apresentar problemas de saúde, por exemplo, ferimentos e/ou infecção na pele, ou se estiver resfriado ou com gastrenterites e circular sem uniforme nas áreas de serviço.

A higienização do local, equipamentos e utensílios são de suma importância, porém além desta rotina deve-ser também remover o lixo 
diariamente, quantas vezes necessário, em recipientes apropriados, devidamente tampados e ensacados, tomando medidas eficientes para evitar a penetração de insetos, roedores e outros animais, impedir a presença de animais domésticos no local de trabalho e seguir um programa de controle integrado de pragas. As periodicidades devem ser diárias no que se diz respeito a pisos, rodapés e ralos; todas as áreas de lavagem e de produção; maçanetas; lavatórios (pias); sanitários; cadeiras e mesas (refeitório); monoblocos e recipientes de lixo. Diário ou de acordo com o uso equipamentos, utensílios, bancadas, superfícies de manipulação e saboneteiras, borrifadores. Semanal paredes; portas e janelas; prateleiras (armários); coifa; geladeiras; câmaras e "freezers". Quinzenal, estoque e estrados. Mensal, luminárias, interruptores, tomadas, telas. Semestral, reservatório de água. O teto ou forro, caixa de gordura, filtro de ar condicionado, de acordo com a necessidade ou regulamentação específica.

No processo de higienização ambiental é obrigatória as etapas lavagem com água e sabão ou detergente, enxágüe, desinfecção química: deixar o desinfetante em contato mínimo de 15 minutos e enxágüe.No caso de desinfecção pelo calor imergir por 15 minutos em água fervente ou no mínimo a $80^{\circ} \mathrm{C}$, não há necessidade de enxágüe. No caso de utilização de máquina de lavar louça, devem ser respeitados os critérios de lavagem de 55 a $65^{\circ} \mathrm{C}$, enxágüe de 80 a $90^{\circ} \mathrm{C} . q$ Quando utilizar álcool 70\%, não enxaguar e deixar secar o ar. Não é permitido, nos procedimentos de higiene, varrer a seco nas áreas de manipulação, fazer uso de panos para secagem de utensílios e equipamentos, o uso de escovas, esponjas ou similares de metal, lã, palha de aço, madeira, amianto e materiais rugosos e porosos, o reaproveitamento de embalagens de produtos de limpeza e usar nas áreas de manipulação, os mesmos utensílios e panos de limpeza utilizados em banheiros e sanitários.

Em questão controle de matérias primas e produtos expostos a venda e fornecedores é importante uma avaliação das condições operacionais dos estabelecimentos fornecedores de matérias-primas, produtos semi-elaborados ou produtos prontos, através de visita técnica, como subsídio para a qualificação e triagem dos fornecedores. No recebimento avalia-se qualitativa e 
quantitativamente o material entregue por um fornecedor onde deve-se observar data de validade e fabricação, fazer avaliação sensorial características organolépticas, cor, gosto, odor, aroma, aparência, textura, sabor e sinestesia (esta avaliação deve estar baseada nos critérios definidos pela ABNT Associação Brasileira de Normas Técnicas - Análise Sensorial de Alimentos E Bebidas - NBR 12806 - 02/93), observar as condições das embalagens: devem estar limpas, íntegras e seguir as particularidades de cada alimento. Alimentos não devem estar em contato com papel não adequado (reciclado, jornais, revistas e similares), papelão ou plástico reciclado, observar as condições do entregador: deve estar com uniforme adequado e limpo, avental, sapato fechado, proteção para o cabelo ou mãos (rede, gorro ou luvas) quando necessário, conferir a rotulagem: deve constar nome e composição do produto, lote, data de fabricação e validade, número de registro no órgão oficial, CGC, endereço de fabricante e distribuidor, condições de armazenamento e quantidade (peso), observar o certificado de vistoria do veículo de transporte, realizar controle microbiológico e físico-químico quando necessário, através do laboratório próprio ou terceirizado e medir as temperaturas, as quais devem estar adequado e serem registradas no ato do recebimento.

Os perecíveis devem cumprir os seguintes critérios de temperatura para congelados: - $18^{\circ} \mathrm{C}$ com tolerância até $-12^{\circ} \mathrm{C}$; resfriados: 6 a $10^{\circ} \mathrm{C}$, conforme especificação do fabricante e refrigerados: até $6^{\circ} \mathrm{C}$ com tolerância a $7^{\circ} \mathrm{C}$.

Os visitantes são todas as pessoas que não fazem parte da equipe de funcionários da área de manipulação ou elaboração de alimentos, são consideradas visitantes, podendo constituir focos de contaminação durante o preparo dos alimentos. Portanto, são considerados visitantes os supervisores, consultores, fiscais, auditores e todos aqueles que necessitem entrar nestas dependências. Para proceder às suas funções, os visitantes devem estar devidamente paramentados com uniforme fornecido pela empresa, como: avental, rede ou gorro para proteger os cabelos e se necessário, botas ou protetores para os pés. Os visitantes não devem tocar nos alimentos, equipamentos, utensílios ou qualquer outro material interno do estabelecimento. Não devem comer, fumar, 
mascar goma (chiclete) durante a visita. Não devem entrar na área de manipulação de alimentos, os visitantes que estiverem com ferimentos expostos, gripes, ou qualquer outro quadro clínico que represente risco de contaminação.

O fluxo de produção compatível com o "lay-out" para a manipulação correta de alimentos. Configuração das áreas de preparação dos alimentos, de modo que o fluxo seja linear, sem cruzamentos de atividades entre os vários gêneros de alimentos. Se não houver áreas separadas para os vários gêneros, deve existir no mínimo um local para pré-preparo (produtos crus) e local para preparo final (cozinha quente e cozinha fria), além das áreas de retorno de bandejas sujas e lavagem de utensílios, evitando a contaminação cruzada, devendo o manual de boas práticas garantir a qualidade higiênico-sanitária dos alimentos.

O armazenamento envolve três procedimentos básicos: Armazenamento sob congelamento: etapa onde os alimentos são armazenados à temperatura de $0^{\circ} \mathrm{C}$ ou menos, de acordo com as recomendações dos fabricantes constantes na rotulagem ou dos critérios de uso, o armazenamento sob refrigeração: etapa onde os alimentos são armazenados em temperatura de $0^{\circ} \mathrm{C}$ a $10^{\circ} \mathrm{C}$, de acordo com as recomendações dos fabricantes constantes na rotulagem ou dos critérios de uso, e estoque seco: etapa onde os alimentos são armazenados à temperatura ambiente, segundo especificações no próprio produto e recomendações dos fabricantes constantes na rotulagem.

A disposição e Controle no armazenamento: os produtos devem obedecer a data de fabricação, sendo que os produtos de fabricação mais antiga são posicionados a serem consumidos em primeiro lugar (PEPS - primeiro que entra primeiro que sai ou pode utilizar o conceito PVPS - primeiro que vence primeiro que sai). Todos os produtos devem estar adequadamente identificados $\mathrm{e}$ protegidos contra contaminação. Os alimentos não devem ficar armazenados junto a produtos de limpeza, químicos, de higiene e perfumaria, produtos descartáveis também devem ser mantidos separados dos itens citados anteriormente, é proibido a entrada de caixas de madeira dentro da área de armazenamentos e manipulação, as caixas de papelão não devem permanecer nos locais de armazenamentos sob refrigeração ou congelamento, a menos que haja um local 
exclusivo para produtos contidos nestas embalagens (exemplo: freezer exclusivo ou câmara exclusiva), os alimentos ou recipientes com alimentos não devem estar em contato com o piso, e sim apoiados sobre estrados ou prateleiras das estantes. Respeitar o espaçamento mínimo necessário que garanta a circulação de ar (10 $\mathrm{cm})$, os alimentos que necessitem serem transferidos de suas embalagens originais devem ser acondicionados de forma que se mantenham protegidos, devendo ser acondicionados em contentores descartáveis ou outro adequado para guarda de alimentos, devidamente higienizados. Na impossibilidade de manter o rótulo original do produto, as informações devem ser transcritas em etiqueta apropriada (vide sistema de etiquetagem), os produtos destinados à devolução devem ser identificados por fornecedor e colocados em locais apropriados separados da área de armazenamento e manipulação. Nunca utilizar produtos vencidos. Quando houver necessidade de armazenar diferentes gêneros alimentícios em um mesmo equipamento refrigerador, respeitar: alimentos para consumo dispostos nas prateleiras superiores; os semi-prontos e/ou pré preparados nas prateleiras do meio e os produtos crus nas prateleiras inferiores, separados entre si e dos demais produtos. As embalagens individuais de leite, ovo pasteurizado e similares podem ser armazenadas em geladeiras ou câmaras, devido seu acabamento ser liso, impermeável e lavável, podem ser armazenados no mesmo equipamento para congelamento ("freezer") tipos diferentes de alimentos, desde que devidamente embalados e separados. 
Anexo 02: Seqüência lógica para aplicação da APPCC

1 - REUNIR A EQUIPE DE APPC

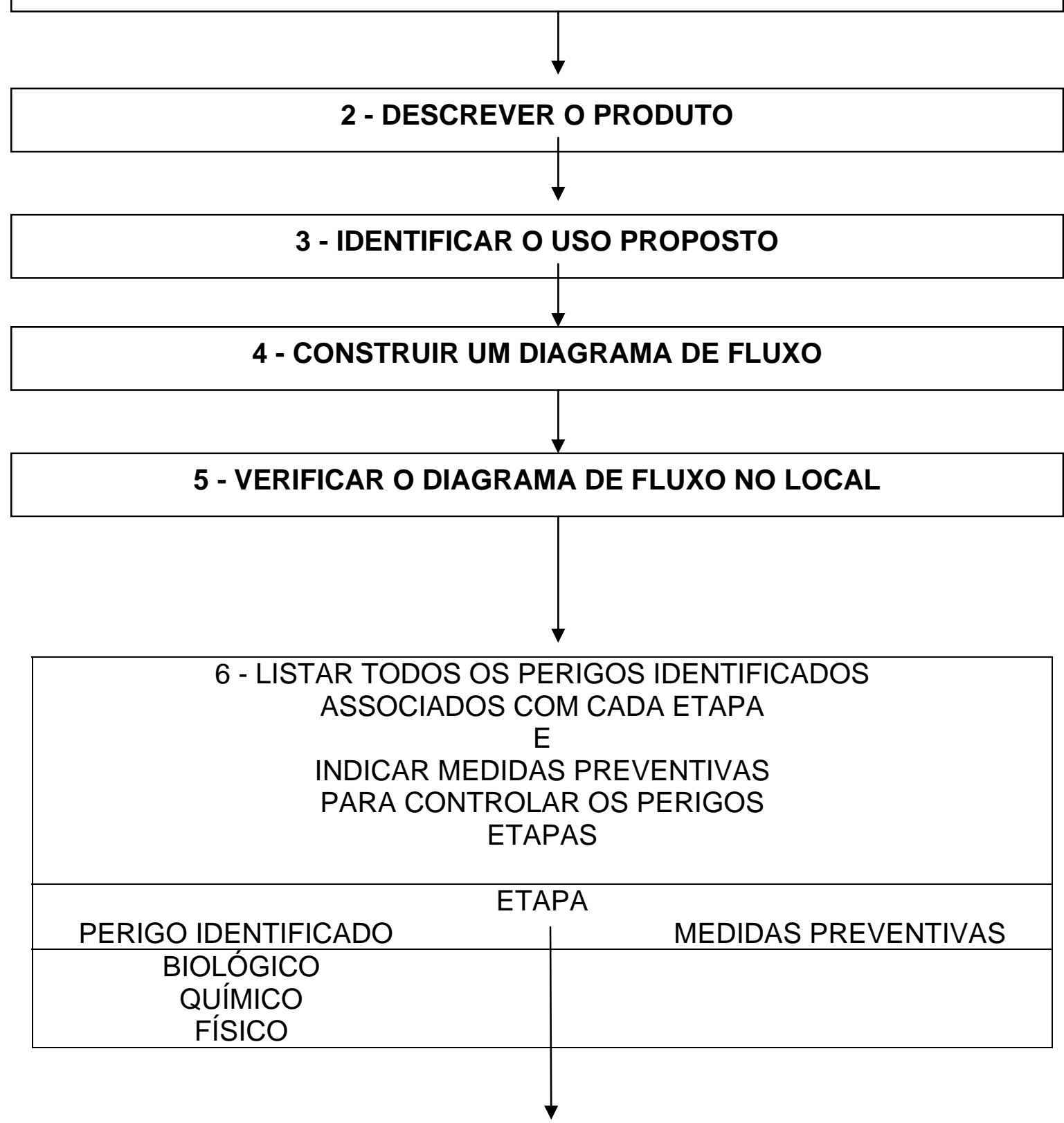


7 - APLICAR A SEQÜÊNCIA DE DECISÕES DO SISTEMA A CADA UMA DAS FASES (RESPONDER EM SEQÜÊNCIA)

P1. EXISTE UMA MEDIDA(S) PREVENTJVA(S)

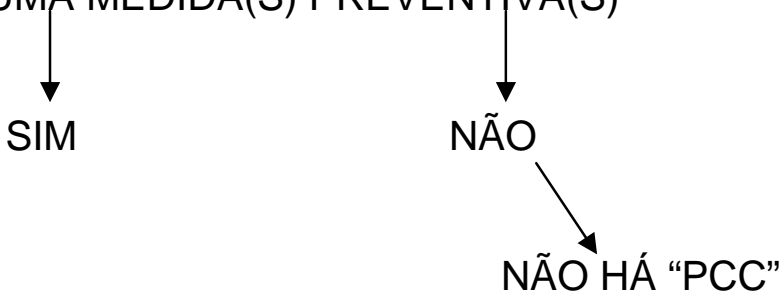

P2. A FASE FOI DESEMPENHADA ESPECIFICAMENTE PARA ELIMINAR A POSSÍVEL OCORRÊNCIA DE UM PERIGO OU PERIGOS OU DIMINUIR A CONTAMINAÇÃO A UM NÍVEL ACEITÁVEL?

SIM

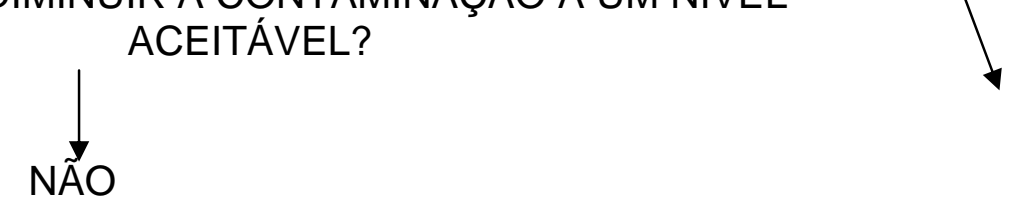

P3. OCORRE A CONTAMINAÇÃO A NÍVEIS QUE SUPERAM OS LIMITES ACEITÁVEIS OU ATINGEM LIMITES INACEITÁVEIS?
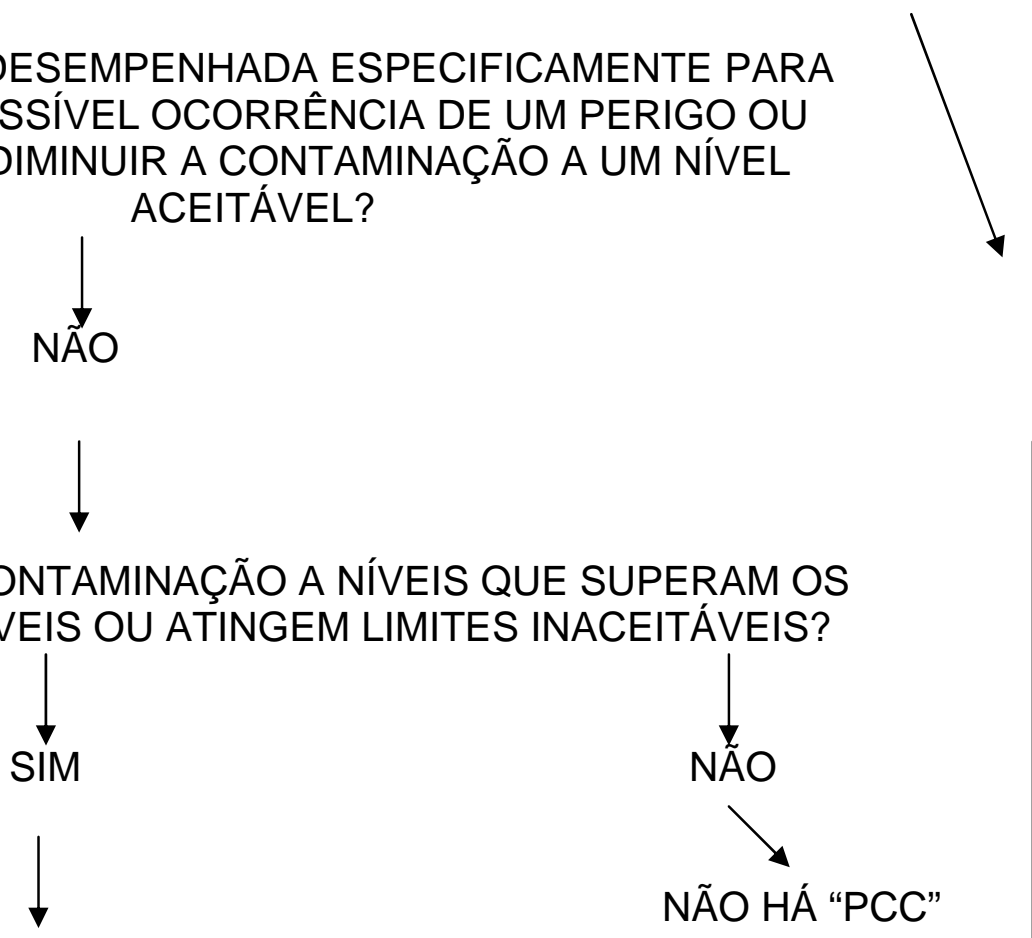

P4. A FASE SEGUINTE ELIMINARÁ O PERIGO OU REDUZIRÁ A PROVÁVEL OCORRÊNCIA A UM NÍVEL ACEITÁVEL?
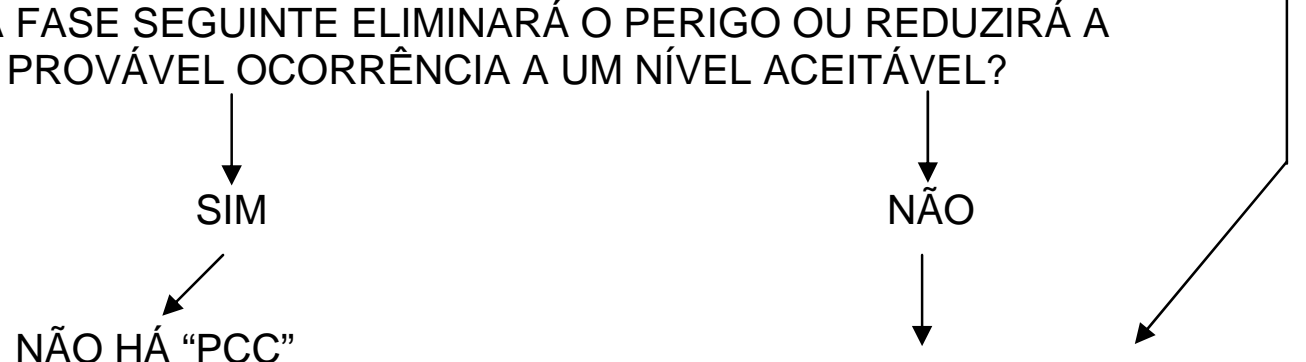

PONTOS CRÍTICOS DE CONTROLE (PCC) 
8. ESTABELECER LIMITES CRÍTICOS PARA CADA PCC

9. ESTABELECER UM SISTEMA DE MONITORAMENTO PARA CADA PCC $\checkmark$

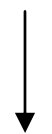

10. ESTABELECER MEDIDAS CORRETIVAS PARA DESVIOS QUE POSSAM OCORRER

11. ESTABELECER PROCEDIMENTOS PARA VERIFICAÇÃO DE TODO SISTEMA DE APPCC

12. ESTABELECER UM SISTEMA DE REGISTROS E DOCUMENTAÇÃO

Fonte: CODEX, 1993. 